\title{
Foreign Direct Investment and Economic Growth in South Africa: A Vector Error Correction (VEC) Model Approach
}

\author{
Allexander Muzenda \\ Assistant Director: Gert Sibande TVET College, Mpumalanga, South Africa \\ Bongani J Mwale \\ Chairperson of Council at Gert Sibande TVET College, Mpumalanga, South Africa \\ Thebogo Portia Percians Mange \\ Principal at Gert Sibande TVET College, Mpumalanga, South Africa \\ Maphefo Anno-Frempong \\ Deputy Chairperson of Council at Gert Sibande TVET College, Mpumalanga, South Africa
}

\begin{abstract}
The objective of this research study was to examine the influence of foreign direct investment on economic growth in South Africa during the period 1994-2014. Time series annual data on real gross domestic product (GDP) growth, foreign direct investment, and terms of trade were sourced from the South African Reserve Bank (SARB) historical macroeconomic statistics online database. Unit root and cointegration properties of data were analysed using Augmented Dickey-Fuller and Johansen cointegration test techniques, respectively. The Vector Error Correction model was applied to compute long-run and short-run parameters of endogenous variables in the model. Results of the long-run section of the cointegrating equation show that for every 1 percent rise in foreign direct investment, there was a statistically significant rise in growth of gross domestic product by about 0.05 percentage points during the period 1994-2014. Results of the error correction component of the gross domestic product growth equation show that about 62 percent of the deviance from the long-run stability pathway was rectified in the first year after the deviation occurred. Results of the impulse response functions indicate that a one standard deviation in foreign direct investment had a statistically significant and positive effect on future gross domestic product growth after the first year.
\end{abstract}

Keywords: Foreign direct investment (FDI), gross domestic product (GDP) growth, Vector Error Correction (VEC) model

DOI: $10.7176 / \mathrm{JESD} / 12-12-01$

Publication date:June $30^{\text {th }} 2021$

\section{Introduction}

The subject of sustainable and high economic growth remains a permanent item on global economic development agenda and numerous macroeconomic policy discussions. In an effort to stimulate economic growth, government and economic policy makers in several economies consider foreign direct investment (FDI) as one of the key instruments that stimulate growth in several developing and emerging economies. Some preceding economic researches which have examined the impact of FDI on gross domestic product (GDP) growth in diverse economies have reported conflicting results. Driven by broad macroeconomic goals to address social and economic challenges which include high levels of unemployment, acute income distribution inequality and deepening poverty in South Africa, attainment of significant FDI inflows remain as one of central policy objectives since the advent of democracy in 1994. Government has to date pursued several policies towards promotion of FDI inflows to augment existing capital stock to drive economic growth. In addition to implementation of investment promotion strategies, supporting policies were adopted, namely Reconstruction and Development Programme (RDP) implemented in 1994, Growth Employment and Redistribution (GEAR) implemented in 1996, Accelerated and Shared Growth Initiative for South Africa (ASGISA) implemented in 2007, New Growth Path (NGP) implemented in 2010, and New Development Plan (NDP) adopted in 2013 (Koma, 2013). South Africa's performance in stimulating FDI stock inflows remains a matter of concern in respect of its low contribution to the world FDI flows (Pietersen, 2015).

\subsection{Problem statement}

South Africa is considered a low-risk investment destination for investors and exports more than $25 \%$ of its manufactured products to the African continent (Mahembe \& Odhiambo, 2013). Through investment incentives and industrial financing interventions, the government aggressively seeks to boost attraction of foreign capital inflows. Based on the United Nations World Investment Report released at United Nations Conference on Trade and Development (UNCTAD, 2015), FDI flows into South Africa plunged by $31.2 \%$ to $\$ 5.8$ billion in 2014 down 
from \$8.3-billion in 2013. World Bank data shows that South Africa experienced declines and volatile changes in FDI inflows between 1994 and 2015 (Figure 1).

Figure 1: FDI inflows_net (\% of BOP, change) and GDP growth (\%) in South Africa

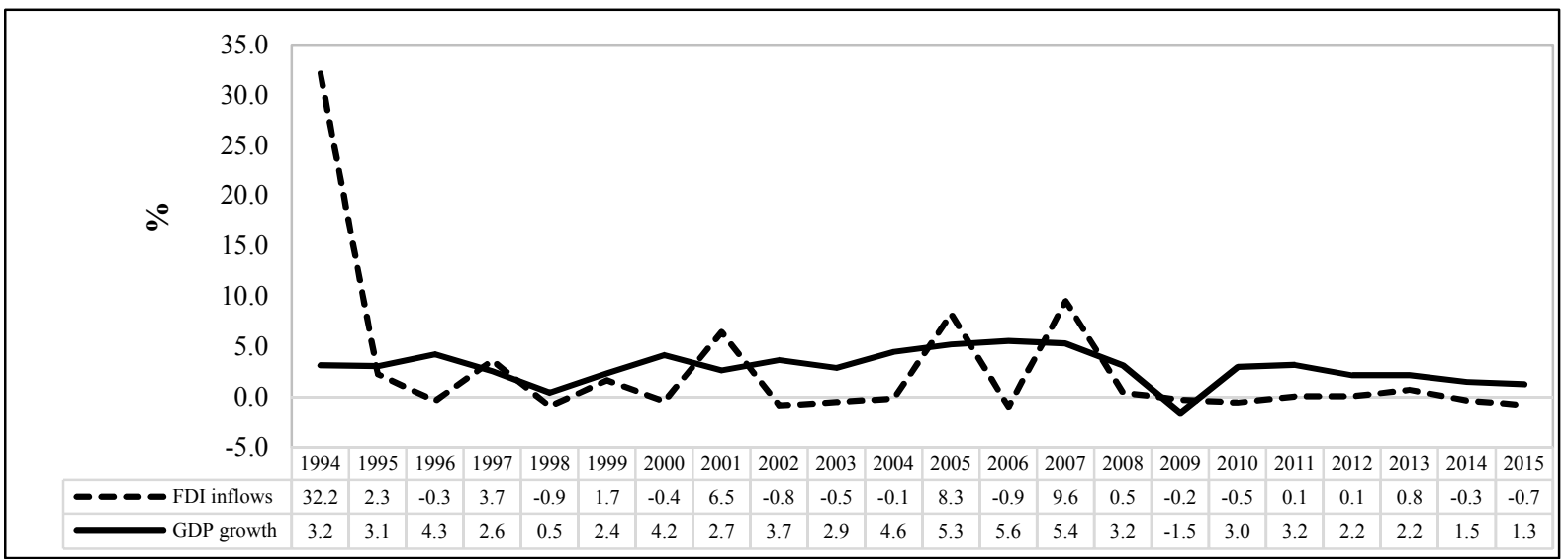

Source: World Bank

The trends of changes in FDI net inflows and GDP growth depicted in Figure 1 show evidence of volatile FDI inflows between 1994 and 2008, while the decline in economic growth was imminent during 2009 when the growth rate plunged to $-0.2 \%$ down from $9.6 \%$ during 2007 . Unless sound economic policy initiatives are implemented, South Africa's economic growth is likely to remain sluggish over the coming years since the country faces a daunting challenge of competing with other emerging economies for the much needed foreign direct investment.

\subsection{Research objective}

- To examine the impact of foreign direct investment on economic growth in South Africa during the period 1994-2014.

\subsection{Research question}

- What is the impact of foreign direct investment on economic growth in South Africa during the period 1994-2014?

\subsection{Research hypothesis}

- Foreign direct investment has a statistically significant and positive impact on economic growth in South Africa.

\section{Literature Review}

Theories on economic growth provide the basis for understanding the role played by direct investments on economic growth in nations (Anyanwu, 2012; and Awan, 2013). The economic theory used in this study is the neoclassical growth model. This theory holds that a steady state growth in an economy is significantly driven by exogenous variables, among which FDI remains as one of the major regressors (Jones, 2015). In respect of that backdrop, FDI in the form of physical stock can be modeled separately as a determinant of national output growth given its major contribution to capital accumulation. Thus, capital accumulation in an economy from FDI greatly impacts on national output growth in both short-run and long-run periods. Following Agar (2014), Jones (2015), and Abushhewa, \& Zarook (2016), a FDI-driven growth model borrows from the specification of aggregate output $(\mathrm{Y})$ in an economy at the current period $\mathrm{t}$ as a function of infrastructure capital $(\mathrm{G})$, other capital $(\mathrm{K})$ and labour (L), such that:

$$
\mathrm{Y}_{\mathrm{t}}=\mathrm{A}_{\mathrm{t}} \mathrm{K}_{\mathrm{t}}^{\alpha} \mathrm{G}_{\mathrm{t}}^{\beta} \mathrm{L}_{\mathrm{t}}^{1-\alpha-\beta}
$$

where $A_{t}$ is aggregate factor productivity at time period t, assuming a fixed savings rate (s), and that infrastructure capital depreciates in each successive time period.

In analysing the dynamic stimuli of FDI on national output growth rate in Nepal, Adhikary (2015) applied the vector error correction (VEC) model to determine whether or not there was a long-term relationship between FDI and national output growth utilising annual time series data for the sample period 1985-2012. Estimates derived after a VEC-based Granger-Causality test was performed provided evidence that FDI had a statistically a substantial favourable effect on national output growth during the sample period 1985-2012. Nonetheless, the 
results from the impulse response analysis performed show that the relationship between FDI and economic growth in Nepal was not stable in volatile times during the period 1985-2012.

Gudaro, Chhapra \& Sheikh (2012) analysed the impact of FDI on economic growth in Pakistan over the sample period 1981 to 2010 . Multiple regressions were employed to examine the link between national gross domestic product (GDP) and overseas direct investment in which GDP was the regressand. Results show a positive and significant association between gross domestic product and FDI. The study concludes that FDI is an essential instrument for national output growth in developing countries through transfer of technology, improvement in competition in markets, improvement in human capital development and contribution to corporate tax revenue in the host country. Antwi \& Zhao (2013) analysed the impact of FDI on GDP growth in Ghana during the period 1980-2010 using cointegration and Vector Error Correction (VEC) model methods. The study found a long-term equilibrium association between FDI and GDP growth in Ghana over the sample period, and the short-run component of the Vector Error Correction model show a significant and positive association between FDI and output growth.

Following the study by Zafar (2013) which investigated the factors influencing inward FDI in BRICS countries using time-series data, Haydaroğlu (2016) further analysed the influence of FDI on growth on BRICS countries, namely Brazil, Russia, India, China and South Africa over the sample period 1995-2013. The pooled ordinary least squares model, fixed effects model and random effects model panel regression techniques were employed in which the suitable method was chosen using the Hausman test. Results show that FDI had a statistically significant and positive impact on national output growth in BRICS nations. Adeleke (2014) analysed the effect of FDI on economic growth at regional level in Africa in aggregated and disaggregated levels. The pooled ordinary least squares (OLS), random effects (RE) and fixed effects (FE) models were applied for estimation in the study. Results from the study reveal that governance in numerous African countries was weak and inhibited FDI inflows and economic growth. Results from the pooled OLS, random effects and fixed effects models all indicate that FDI had a significant and positive impacts on growth in the African continent. Findings in the study conform to results found by Casillas \& Acedo (2013) and Abdoulaye, Xie \& Oji-Okoro (2015).

Mahembe \& Odhiambo (2013) analysed the changing aspects of overseas direct investment in SADC nations based on evidence from five middle-income economies. The economies include South Africa, Botswana, Zambia, Lesotho and Swaziland. The study points out that in 1980s and 1990s, these nations were characterised by protectionist policies, especially towards small industries from overseas competition, and external direct investment was low throughout that period. However, at the end of 1990s and beginning of the 2000s, these countries embarked on new policies on privatization, liberalization and FDI regulatory reviews. The countries' policy authorities also ensured reductions in misalignments and volatilities of exchange rates, which impede export growth (Ganyaupfu, 2013), in order to boost foreign direct investment inflows which further promote growth. In line with Ganyaupfu (2013), Adhikary (2017) finds empirical evidence that exchange rates significantly affect economic growth in South Asian economies. However, FDI inflows in several nations remain low due to many constraining factors which include political insecurity, policy unpredictability and business climate Sherif \& Dalia, 2014).

\section{Methodology}

\subsection{Data}

Time-series annual data on GDP growth (GDPg), foreign direct investment (FDI) and terms of trade (ToT) during the sample period 1994-2014 were sourced from the South African Reserve Bank (SARB) historical macroeconomic online data portal.

\subsection{Stationarity tests}

Given that the actual data generation process is not known, the univariate unit root tests were conducted to establish the order of integration of the data series. The Augmented Dickey Fuller (ADF) test criterion was used for the series in levels, as well as at first differences at intercept.

\subsection{VAR lag order selection}

Optimal lags were chosen using LR statistic, final prediction error (FPE), Akaike information criterion (AIC), Schwarz information criterion (SIC) and Hannan-Quinn information criterion (HQIC). Determination of the optimal lags was done for cointegration and Granger causality.

\subsection{Cointegration test}

Since variables had unit roots, the Johansen (1988) test was used to test for long run relationship between variables to identify the number of cointegrating vectors. The cointegrating vectors provides an indication of the number of cointegrating equations that were estimated in the VEC model. The time-series cointegrating relationship was therefore be specified as: 


$$
\left(\mathrm{GDP}_{\mathrm{g}}\right)_{\mathrm{t}}=\alpha+\beta(\mathrm{FDI})_{\mathrm{t}}+\mu_{\mathrm{t}}
$$

The gross domestic product (GDP) growth model would be strongly statistically significant if and only if the I(1) processes of the respective variables are cointegrated and $\beta$ is nearly or exactly equal to 1 . Conversely, the model can be weakly statistically significant if GDP growth and FDI are cointegrated and $0<\beta<1$. In addition, if growth and FDI are I(1) process, variables would be cointegrated, implying existence of an error correction mechanism.

\subsection{Vector error correction (VEC) model estimation}

Denoting the gross domestic product growth and foreign direct investment by GDP $_{g}$ and FDI; respectively, the estimated VEC model (Andrei \& Andrei, 2015) is given in equation (3) below:

$$
\left(\mathrm{GDP}_{\mathrm{g}}\right)_{\mathrm{t}}=\beta_{1}+\beta_{2}(\mathrm{GDP})_{\mathrm{t}-1}+\beta_{3}(\mathrm{FDI})_{\mathrm{t}-1}+\varepsilon_{\mathrm{t}}
$$

The one period lag of $\mathrm{GDP}_{\mathrm{g}}$ variable was added (equation 2) to measure the speed of adjustment to the long-run equilibrium path. Given the procedure followed in estimating equations of the VEC model, a set of two equations was specified to estimate short-and long-run parameters:

$$
\begin{aligned}
& \Delta\left(\mathrm{GDP}_{\mathrm{g}}\right)_{\mathrm{t}}=\alpha_{11}+\pi_{12}\left[\left(\mathrm{GDP}_{\mathrm{g}}\right)_{\mathrm{t}-1}-\theta_{12}(\mathrm{FDI})_{\mathrm{t}-1}-\theta_{13}\right]+\varphi_{11} \Delta\left(\mathrm{GDP}_{\mathrm{g}}\right)_{\mathrm{t}-1}+\varphi_{12} \Delta(\mathrm{FDI})_{\mathrm{t}-1}+\varepsilon_{11 \mathrm{t}} \\
& \Delta(\mathrm{FDI})_{\mathrm{t}}=\alpha_{21}+\pi_{13}\left[\left(\mathrm{GDP}_{\mathrm{g}}\right)_{\mathrm{t}-1}-\theta_{12}(\mathrm{FDI})_{\mathrm{t}-1}-\theta_{13}\right]+\varphi_{21} \Delta\left(\mathrm{GDP}_{\mathrm{g}}\right)_{\mathrm{t}-1}+\varphi_{22} \Delta(\mathrm{FDI})_{\mathrm{t}-1 \mathrm{t}}+\varepsilon_{21 \mathrm{t}}
\end{aligned}
$$

Given the nature of the VEC model, empirical estimation was undertaken as a model containing two functions (4) and (5); where $\left(\mathrm{GDP}_{\mathrm{g}}\right)_{\mathrm{t}-1}-\theta_{12}(\mathrm{FDI})_{\mathrm{t}-1}-\theta_{13}$ in (4) and (5) denote the deviation of GDP growth from the long run relationship given by:

$$
\left(\mathrm{GDP}_{\mathrm{g}}\right)_{\mathrm{t}-1}=\theta_{12}(\mathrm{FDI})_{\mathrm{t}-1}+\theta_{13}
$$

The parameter $\pi_{12}$ in denotes an error correction term (ECT) computed from an error correction mechanism (ECM). The ECT that captures the response of GDP growth to deviations from the long-run equilibrium path was specified in equation (42), while a VEC model approach further estimated the GDP growth function given by (3) as a model containing (4) and (5); yielding:

$$
\Delta \mathrm{Z}_{\mathrm{t}}=\varpi \mathrm{Z}_{\mathrm{t}-1}+\sum_{\mathrm{t}=\mathrm{i}}^{\mathrm{k}} \xi_{\mathrm{i}} \Delta \mathrm{Z}_{\mathrm{t}-1}+\mathrm{c}_{\mathrm{t}}+\varepsilon_{\mathrm{kt}}
$$

where $Z_{t}$ denotes a $3 \times 1$ vector containing I(1) endogenous variables (GDP growth, FDI and a constant), $\xi_{\mathrm{i}}$ represents the $2 \times 2$ short-run coefficient matrices, $c_{t}$ is a vector containing constants, and $\varepsilon_{\mathrm{kt}}$ denotes IDD error terms.

The parameter $\varpi$ was further decomposed into $\tau$ and $\vartheta$ 'matrices; yielding:

$$
\varpi Z_{t-1}=\tau \vartheta^{\prime} Z_{t-1}=\left[\begin{array}{c}
\tau_{11} \\
\tau_{12}
\end{array}\right]\left[1-\vartheta_{12}-\vartheta_{13}\right]\left[\begin{array}{c}
\left(\mathrm{GDP}_{\mathrm{g}}\right)_{\mathrm{t}-1} \\
(\mathrm{FDI})_{\mathrm{t}-1} \\
1
\end{array}\right]
$$

where: $\tau$ denotes a $2 \times 1$ matrix of two variables with at least 1 cointegrating relationship that contains the longrun equilibrium adjustment parameter; and $\vartheta^{\prime}$ represents a $1 \times 3$ matrix containing long run parameters, including a constant.

\subsection{VEC Granger causality/block exogeneity Wald test}

Short run causality between GDP growth and FDI (Aregbesola, (2014) were tested using Granger causality/block exogeneity Wald test based on the functional form:

$$
(\mathrm{X}-3 \mathrm{q}-1)\left(\log \left|\sum_{\mathrm{ab}}\right|-\log \left|\sum_{\mathrm{mn}}\right|\right) \sim \chi^{2}(2 \mathrm{p})
$$

where $\mathrm{X}$ denotes observations, $\sum_{\mathrm{mn}}$ is the variance or covariance conditions of unobstructed VAR structure, $\sum_{\mathrm{ab}}$ denotes the variance or covariance conditions of the constrained system, and q represents the figure of lags of the variable that was eliminated from the structure. 


\subsection{Impulse response function}

Since the VEC Granger causality/block exogeneity Wald test does not provide information on the direction of effect of one $(\mathrm{X})$ variable on the other $(\mathrm{Y})$ variable, as well as the time horizon it takes the variable $\mathrm{Y}$ to return to the long run equilibrium path due to a shock in variable $\mathrm{X}$, the impulse response function analysis was performed. Therefore, impulse response functions (IRFs) were conducted to analyse impacts of shocks on the adjustment path of endogenous variables in the system, specified by the function:

$$
\operatorname{IR}\left(\mathrm{a}, \mathrm{b}, \mathrm{X}_{\mathrm{t}-1}\right)=\mathrm{G}\left(\mathrm{y}_{\mathrm{t}+\mathrm{m}} \mid \mathrm{e}_{\mathrm{t}}=\mathrm{a}, \mathrm{X}_{\mathrm{t}-1}\right)-\mathrm{G}\left(\mathrm{y}_{\mathrm{t}+\mathrm{m}} \mid=\mathrm{X}_{\mathrm{t}-1}\right)
$$

where: a symbolizes time, $\mathrm{b}\left(\mathrm{b}_{1}, \ldots, \mathrm{b}_{\mathrm{m}}\right)$ is $\mathrm{n} \times 1$ vector that denotes the size of shock, $\mathrm{X}_{\mathrm{t}-1}$ denotes accumulative information about the economy from the past period up to time period $t-1$. Given role played by $h$ in the associations of the attributes of the IRF, the orthogonalised impulse response (OIR) was determined by classifying shocks through Cholesky decompositions.

\section{Results and Analysis}

\subsection{Descriptive statistics}

\section{Table 1: Descriptive statistics}

\begin{tabular}{l|cc}
\hline \multirow{2}{*}{ Mean } & $\log ($ GDP growth $)$ & $\log ($ FDI $)$ \\
\cline { 2 - 3 } Median & 1.092118 & 12.47323 \\
Max & 1.147276 & 12.18322 \\
Min & 1.722767 & 14.34088 \\
S.D. & -0.693147 & 11.12281 \\
SW & 0.533161 & 0.934771 \\
KS & -1.836783 & 0.564055 \\
J.B & 7.395119 & 2.281341 \\
Prob & 27.34346 & 1.490919 \\
\hline
\end{tabular}

The average GDP growth and FDI were 1.1 percent and R12.4 billion; respectively during 1994 to 2014. Concomitant standard deviations were $0.5 \%$ for GDP growth and 0.93 billion for FDI, and minimum GDP growth rate was $-0.6 \%$ while maximum GDP growth rate was $1.7 \%$. FDI minimum and maximum values were R11.1 billion and R14.3 billion, respectively.

\subsection{Vector autoregression (VAR) lag order selection}

The VAR-based lag order selection criteria were used to determine the optimal number of lags applied in the econometric estimation process (Table 2).

Table 2: VAR lag order selection criteria

Endogenous variables: $\log ($ GDP growth) $\log (\mathrm{FDI})$

Exogenous variables: $\operatorname{dlog}(\mathrm{TOT}(-1))$

\begin{tabular}{lllllll}
\hline Lag & LogL & LR & FPE & AIC & SC & HQ \\
\hline 0 & -65.75053 & NA & 54.78303 & 9.678647 & 9.769941 & 9.670196 \\
1 & -5.209245 & $95.13631^{*}$ & $0.017233^{*}$ & $1.601321^{*}$ & $1.875202 *$ & $1.575968^{*}$ \\
2 & -3.226915 & 2.548711 & 0.024226 & 1.889559 & 2.346029 & 1.847305 \\
3 & -0.039035 & 3.187880 & 0.031025 & 2.005576 & 2.644634 & 1.946420 \\
\hline
\end{tabular}

* shows lag order chosen, LR: sequential modified LR test statistic (5\% level), FPE: Final prediction error AIC: Akaike information criterion, SC: Schwarz information criterion, and HQ: Hannan-Quinn information criterion

The lag equal to 1 was the optimal length chosen at 5\% significance level. Estimations in which the chosen optimal lag length was used include the cointegration test, VEC model, diagnostic tests (Bollerslev, 1986) and the impulse response functions.

\subsection{Stationarity tests}

The results on the univariate stationarity tests (Table 3) were computed using the Augmented Dickey Fuller (ADF) criterion. The respective tests were performed to determine the order of integration of each variable (GDP growth and FDI), and assess suitability of testing whether or not these variables jointly had a long-run relationship. 
Table 5.3: Unit root tests

\begin{tabular}{llllll}
\hline \multirow{2}{*}{ Data series } & \multirow{2}{*}{ Lag length } & \multicolumn{2}{c}{ Critical values } & \multirow{2}{*}{ t-statistic } & Prob. $^{\dagger}$ \\
\cline { 3 - 5 } & & $\alpha=1 \%$ & $\alpha=5 \%$ & -2.6903 & 0.0949 \\
\hline $\log ($ GDP growth $)$ & 0 & -3.8573 & -3.0404 & $-4.1387^{*}$ & 0.0079 \\
$\mathrm{~d}(\log ($ GDP growth) $)$ & 1 & -4.0044 & -3.0989 & 0.9335 & 0.9938 \\
\hline $\log (\mathrm{FDI})$ & 0 & -3.8085 & -3.0207 & $-3.5224^{* *}$ & 0.0189 \\
$\mathrm{~d}(\log (\mathrm{FDI}))$ & 0 & -3.8315 & -3.030 & -0.4204 & 0.8877 \\
\hline $\log ($ ToT $)$ & 1 & -3.8085 & -3.0207 & $-7.0190^{*}$ & 0.0000 \\
\hline $\mathrm{d}(\log ($ ToT $))$ & 1 & -3.8574 & -3.0404 & $\left.{ }^{* * *}\right)$
\end{tabular}

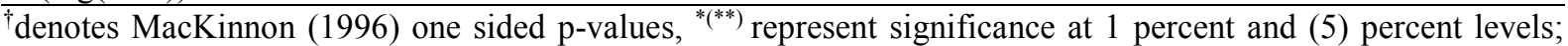
respectively.

The selection of proper lag length of the ADF unit root tests was determined automatically by EViews program

Based on results (Table 3), all the endogenous variables (GDP growth and FDI), as well as the exogenous variable Terms of Trade (ToT), contained a unit root at level, which implies that each of the variables was not stationary at level. Results show that GDP growth series at first difference was I(1) at 1 percent level of significance, while FDI series at first difference was stationary at 5 percent significance level. Similarly, ToT series at first difference was stationary at 1 percent significance level.

\subsection{Cointegration test statistics}

The determination of cointegrating relationships between the endogenous series GDP growth and FDI; factoring in the exogenous series Terms of Trade (ToT), was performed using the Johansen Trace and Max-Eigen statistics approach (Table 4).

Table 4: Cointegration test results-No deterministic trend, interval: 1 to 1

\begin{tabular}{lll}
\hline $\mathrm{H}_{0}$ & $\mathrm{r}=0$ & $\mathrm{r} \leq 1$ \\
$\mathrm{H}_{1}$ & $\mathrm{r}=1$ & $\mathrm{r}=2$ \\
\hline Trace statistic & $13.15862^{*}$ & 3.526473 \\
Critical value & 12.32090 & 4.129906 \\
Prob.* $^{* *}$ & 0.0361 & 0.0716 \\
\hline Max-Eigen statistic & 9.632150 & 3.526473 \\
Critical value & 11.22480 & 4.129906 \\
Prob. & & 0.0716 \\
\hline
\end{tabular}

*denotes rejection of the null hypothesis at 5\% significance level, ${ }^{* *}$ MacKinnon-Haug-Michelis (1999) p-values

Table 4 results show that the Trace statistic shows existence of 1 cointegrating equation at 5 percent significance level. The null hypothesis that $\mathrm{r}=0$ was rejected at 5 percent significance level. However, the Maximum Eigenvalue statistic suggests that there was no cointegration between GDP growth and FDI. Thus, based on results of the Trace statistic, the indication that there was cointegration between GDP growth and FDI suggests that the series was suitable for econometric estimation of their dynamic inter-relationships using the VEC model.

\subsection{VEC model estimates}

Table 5 presents results from the VEC estimation of the data used in this analysis. 
Table 5: VEC model estimates

\begin{tabular}{|c|c|c|}
\hline Cointegrating Equation: & CointEq1 & \\
\hline $\begin{array}{l}\log (\text { GDP growth}(-1)) \\
\log (\text { FDI }(-1))\end{array}$ & $\begin{array}{r}1.000000 \\
-0.048336 \\
(0.02371) \\
{[-2.03898]}\end{array}$ & \\
\hline Error Correction: & $\mathrm{d}(\log ($ GDP growth $))$ & $\mathrm{d}(\log (\mathrm{FDI}))$ \\
\hline Coint Eq1 & $\begin{array}{c}-0.624233 \\
(0.31270) \\
{[-1.99625]}\end{array}$ & $\begin{array}{r}0.141414 \\
(0.08560) \\
{[1.65211]}\end{array}$ \\
\hline $\mathrm{d}(\log ($ GDP growth$(-1)))$ & $\begin{array}{c}0.089717 \\
(0.30244) \\
{[0.29665]}\end{array}$ & $\begin{array}{c}-0.170711 \\
(0.08279) \\
{[-2.06209]}\end{array}$ \\
\hline $\mathrm{d}(\log (\mathrm{FDI}(-1)))$ & $\begin{array}{c}0.844889 \\
(0.74514) \\
{[1.13387]}\end{array}$ & $\begin{array}{c}0.471964 \\
(0.20397) \\
{[2.31394]}\end{array}$ \\
\hline $\mathrm{d}(\log (\mathrm{ToT}(-1))$ & $\begin{array}{c}4.071735 \\
(5.46296) \\
{[0.74533]}\end{array}$ & $\begin{array}{r}-1.200218 \\
(1.49537) \\
{[-0.80262]}\end{array}$ \\
\hline $\begin{array}{l}\mathrm{R}^{2} \\
\text { Adj. } \mathrm{R}^{2} \\
\text { Sum }{ }^{2} \text { resids } \\
\text { Std. Err. } \\
\text { F-statistic } \\
\text { Log likelihood } \\
\text { AIC } \\
\text { SIC } \\
\text { Mean dep } \\
\text { S.D. dep }\end{array}$ & $\begin{array}{r}0.308947 \\
0.136184 \\
4.827008 \\
0.634232 \\
1.788272 \\
-13.11612 \\
2.139515 \\
2.332662 \\
-0.043261 \\
0.682398\end{array}$ & $\begin{array}{r}0.100133 \\
-0.124834 \\
0.361676 \\
0.173608 \\
0.445102 \\
7.613754 \\
-0.451719 \\
-0.258572 \\
0.153093 \\
0.163691\end{array}$ \\
\hline $\begin{array}{l}\text { Determinant resid covariance (dof adj.) } \\
\text { Determinant resid covariance } \\
\text { Log likelihood } \\
\text { Akaike information criterion } \\
\text { Schwarz criterion }\end{array}$ & & $\begin{array}{r}0.012122 \\
0.006818 \\
-5.501062 \\
1.937633 \\
2.420501 \\
\end{array}$ \\
\hline
\end{tabular}

() and [ ] represent standard errors and t-statistics; respectively

The computed estimates of the long run section of the cointegrating equation reveal that for every 1 percent increase in foreign direct investment (FDI), there was a statistically significant corresponding increase in gross domestic product (GDP) growth by approximately 0.05 percent during the period 1994-2014. The negative sign in the facade of the computed figure of the long-run section of the cointegrating equation illustrates a positive association between the variable to which the computed figure relates and a factor on which the vector was standardized (Dhungel, 2014; and Hussain \& Haque, 2016). In conformity to Mazenda (2014) who reported a GDP growth speed of adjustment of about 29 percent in South Africa, results of the error correction component of the GDP growth equation in this study reveal that about 62 percent of the deviance from the long-run equilibrium trajectory was rectified in the first year following occurrence of the deviance during the period 1994-2014. The respective result further conforms to the finding by Hussain \& Haque (2016) which reports evidence of approximately 52 percent GDP promptness of correction to the long-term equilibrium in Bangladesh during the sample period 1973-2014. The computed t-statistics for the error correction and cointegration equations were statistically significant at 5\% level (Engle \& Granger, 1987).

Though statistically insignificant, the positive impact of terms of trade (ToT) on GDP growth in the short run demonstrates that GDP growth marginally reacted to movements in the nation's trade integration as measured by 
terms of trade. The result suggests that for every 1 percentage point increase in the lagged terms of trade index, there was a parallel marginal rise in GDP growth by about 4 percentage points. Nonetheless, though the result shows evidence that lagged terms of trade (proxy for economy's integration into global trade), may FDI, the influence was statistically insignificant. However, terms of trade had a statistically insignificant impact on FDI over the sample period 1994-2014. The result conforms to Kalumbu \& Sheefeni (2014) who found that terms of trade had a negative impact on FDI and growth in Namibia during the period 1980 to 2012. Hussain \& Haque (2016) found that trade had an insignificant effect on FDI and growth in Bangladesh during 1973-2014. The Fstatistic ( $p>0.05$ ) shows that the null hypothesis that all slope coefficients are jointly equal to zero. To determine short-run causality between GDP growth and FDI, VEC Granger causality/block exogeneity tests were performed.

Table 6: VEC Granger causality/block exogeneity Wald tests

\begin{tabular}{lccc}
\hline Panel A - Dep variable: $d(\log ($ GDP growth $))$ & & \\
\hline Excluded & Chi-square & df & Prob. \\
\hline $\mathrm{d}(\log ($ FDI $))$ & 1.285659 & 1 & 0.2568 \\
All & 1.285659 & 1 & 0.2568 \\
\hline Panel B - Dep variable: $d(\log ($ FDI $))$ & & & \\
\hline Excluded & Chi-square & df & Prob. \\
\hline d(log(GDP growth) $)$ & 4.252200 & 1 & 0.0392 \\
All & 4.252200 & 1 & 0.0392 \\
\hline
\end{tabular}

Table 6 results on the joint test p-values for the respective equations of GDP growth and FDI show that the respective variables were exogenous in nature during the period under review. Based on Panel A, the null hypothesis that FDI does not Granger GDP growth could not be rejected based on the insignificant Chi-square statistic $(p>0.05)$ at 5 percent significance level, hence FDI does not Granger cause GDP growth. This result conforms to the finding by Aga (2014) which revealed that FDI does not Granger-cause GDP growth in Turkey during the period 1980-2014. The result implies that the lagged difference of the FDI variable could be excluded in the differenced GDP growth equation. However, Panel B results show that the null hypothesis that GDP growth does not Granger cause FDI ratio was rejected at 5 percent level of significance, implying that GDP growth Granger-caused FDI during the period 1994-2014.

Based on the finding that GDP weakly Granger-caused FDI in a panel of developing countries reported by Mahmoodi \& Mahmoodi (2014), the results in this study which revealed that GDP Granger-caused FDI therefore implies that the lagged difference of GDP growth equation could not be excluded in the differenced FDI equation. Generally, results suggest no evidence of causality from FDI to GDP growth at 5\% significance level, while there was proof of one-way causality from GDP growth to FDI over the period under review. Although the aboveexplained results were reported no information was provided on the impact of one-standard deviation innovation of one variable on itself and the other variable. To derive such evidence, impulse response functions were performed, and the computed results are presented in Table 7.

\subsection{Diagnostic tests of the VEC residual}

The estimated VEC model residual diagnostic tests were examined to assess model robustness.

Table 7: VEC Model Residual Tests ${ }^{\dagger}$

\begin{tabular}{lllll}
\hline Residual test & Measurement & Chi-square & df & Prob. \\
\hline Serial LM test & LM-stat & 3.925294 & 4 & 0.4162 \\
Normality test & Jacque-Bera & 2.385657 & 4 & 0.6652 \\
Heteroskedasticity & No cross terms & 22.59773 & 24 & 0.5436 \\
\hline
\end{tabular}

$\dagger$ indicates that results reported are for the joint tests

The estimated VEC model passed all the residual diagnostic tests. The correlograms show that there potentially was no material autocorrelation left behind in the residuals.

\subsection{Impulse response functions}

The impulse response functions computed from the estimated VEC model were derived using orthogonalised Cholesky decomposition, and results are presented in Figure 1. 
Figure 1: Response to a one standard deviation over a 21 year (1994-2014) period

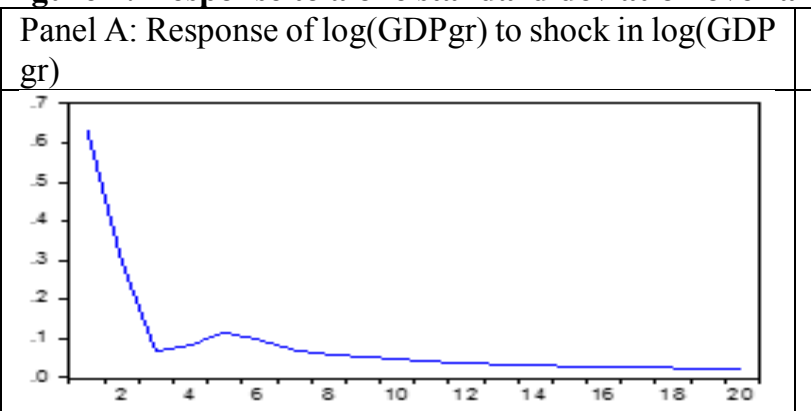

Panel B: Response of $\log$ (GDP growth) to shock in $\log (\mathrm{FDI})$

Panel C: Response of $\log (\mathrm{FDI})$ to shock in $\log (\mathrm{GDP}$ growth)
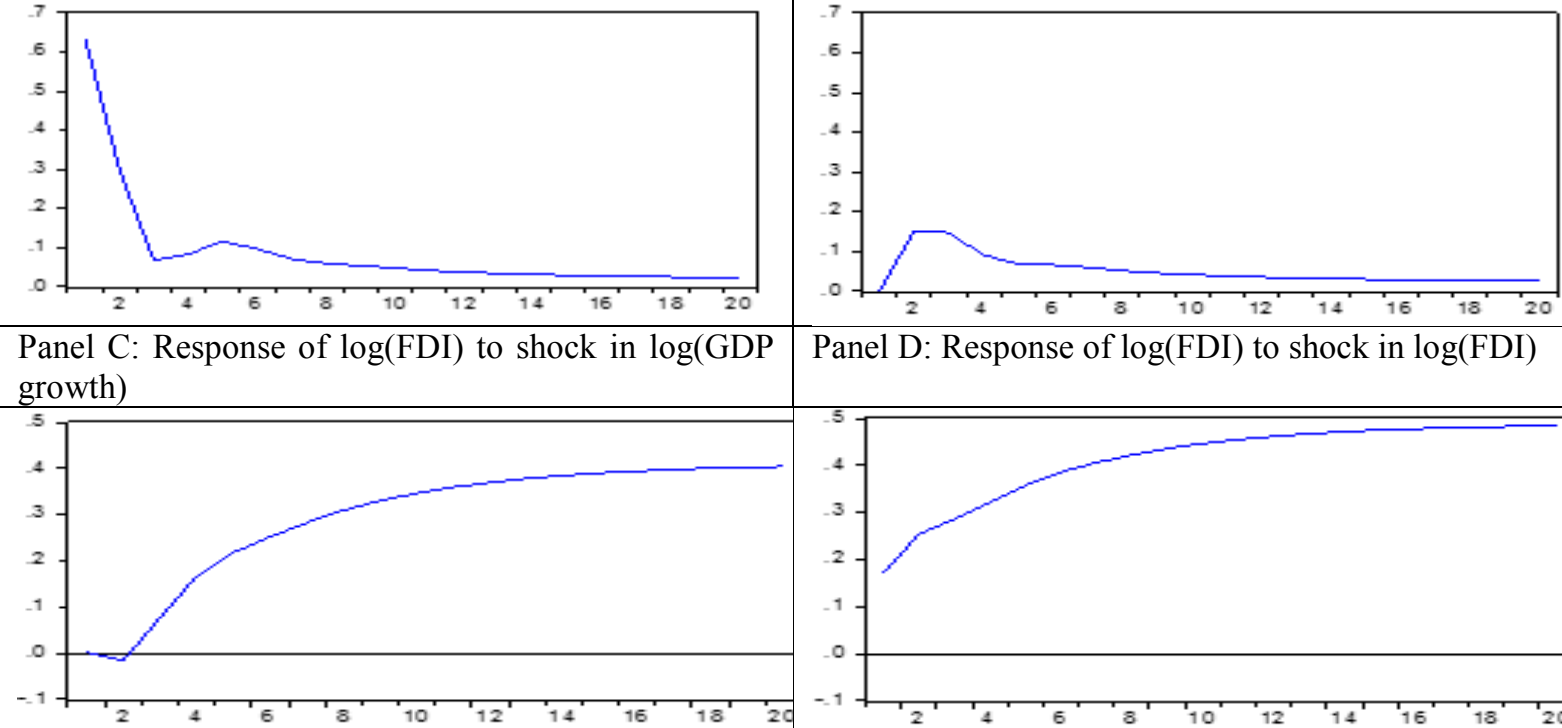

The impulse response function in Panel A reveals that the shock to GDP growth had a significant favourable impact on GDP growth throughout the entire sample time frame 1994-2014. The impact however drastically reduced between the $1^{\text {st }}$ year and the $3^{\text {rd }}$ year after the shock, and marginally improved between the $3^{\text {rd }}$ year and the $5^{\text {th }}$ year. Though remaining statistically significant, the shock steadily declined from the $5^{\text {th }}$ year and remained relatively stable the $8^{\text {th }}$ year and the $20^{\text {th }}$ year during the sample period under review. Panel B shows that an innovation in FDI had a favourable influence on future GDP growth after the first year. Though the magnitude of the impact steadily reduced from the $3^{\text {rd }}$ year, the innovation remained stable and statistically significant and favourable from the $4^{\text {th }}$ year throughout to the $20^{\text {th }}$ year. Panel $\mathrm{C}$ results provide evidence that a shock emanating from GDP growth to FDI had a statistically significant and favourable impact on future FDI from the $2^{\text {nd }}$ year through to the $20^{\text {th }}$ year. Similarly, the impact of a one standard deviation innovation to FDI on FDI was favourable and statistically significant throughout the sample period. Analysis of the impact of an exogenous shock to one variable directly on itself and another variable was performed on the short-to-long term (21 year) horizon based on the orthodox postulation that the economy returns to the equilibrium path in the long run.

\subsection{VEC model estimates stability test}

The stability condition of the VEC model estimates is demonstrated in Figure 2, which shows that all roots have modulus less than one and generally lie inside the unit circle.

Figure 2: VEC estimates stability test
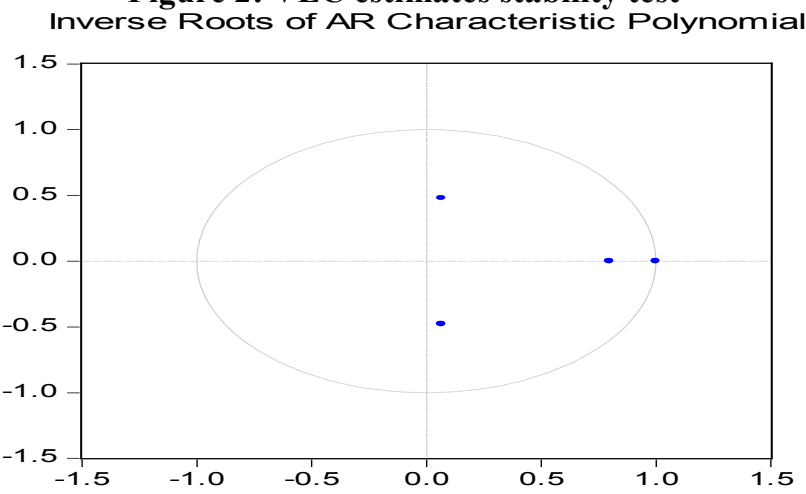

The presence of 1 unit root satisfies the condition that when a VEC model has been estimated from a single cointegrating relation with two variables, then a characteristic polynomial should have 1 root equal to unity. Results of the VECM estimation thus satisfy the stability condition.

\section{Conclusion and Recommendations}

Based on results from this study, increases in foreign direct investment significantly lead to economic growth in the country. Government policy makers should realise that, through the multiplier effect, improvement in 
economic growth can further lead to labour absorption, thus reduction in poverty levels. In order to attract foreign direct investment inflows, government should maintain fiscal discipline (Ganyaupfu, 2014) and constantly ensure fiscal sustainability through monitoring public debt trajectories (Ganyaupfu \& Robinson, 2019) to avoid crowding out effect, while monetary authorities should monitor the exchange rate and maintain stable interest rates to ensure sustainable attraction of significant foreign direct investment inflows. In respect of future studies, a relatively larger sample size comprising additional data for latest available annual periods can be used to examine the trajectories in net inflows of foreign direct investment and its impact on growth using other suitable econometric estimation methods. In addition, more relevant exogenous variables which affect growth (Sankran, 2015) should also be incorporated and examined in the model to improve the robustness of the results.

\section{References}

Abdoulaye, O. B., Xie, K. \& Oji-Okoro, I. (2015). Strategies and Determinants of Foreign Direct Investment (FDI) Attraction. International Journal of Management Science and Business Administration, 1(5), 81-89.

Abushhewa, A. A. \& Zarook, T. (2016). The Effects of Foreign Direct Investment on Economic Growth in Libya: A Causality Analysis. Open Science Journal, 1(2), 1-15.

Adeleke, A. I. (2014). FDI-Growth Nexus in Africa: Does Governance Matter? Journal of Economic Development, 39(1), 111-135.

Adhikary, B. K. (2015). Dynamic Effects of FDI, Trade Openness, Capital Formation and Human Capital on the Economic Growth Rate in the Least Developed Economies: Evidence from Nepal. International Journal of Trade, Economics and Finance, 6(1): 1-7.

Agar, A. A. K. (2014). The Impact of Foreign Direct Investment on Economic Growth: A Case Study of Turkey 1980-2012. International Journal of Economics and Finance, 6(7), 71-84.

Andrei, D. M. \& Andrei, L. C. (2015). Vector error correction model in explaining the association of some macroeconomic variables in Romania. Procedia Economics and Finance, 22, 568-576.

Antwi, S. \& Zhao, X. (2013). Impact of Foreign Direct Investment on Economic Growth in Ghana: A Cointegration Analysis. International Journal of Business and Social Research, 3(1), 64-74.

Anyanwu, J. C. (2012). Why Does Foreign Direct Investment Go Where It Goes? New Evidence from African Countries. Annals of Economics and Finance, 13(2), 433-470.

Anyanwu, J. C. \& Yameogo, N. D. (2015). What Drives Foreign Direct Investments into West Africa? An Empirical Investigation. African Development Review, 27(3), 199-215.

Aregbesola, A. R. (2014). Foreign Direct Investment and Institutional Adequacy: New Granger Causality Evidence from African Countries. South African Journal of Economic and Management Sciences, 17(5), $557-$ 568.

Awan, A. G. (2013). Diverging trends of human capital in BRICS countries. International Journal of Asian Social Science, 2(12), 2195-2219.

Bollerslev, T. (1986). Generalized Autoregressive Conditional Heteroscedasticity, Journal of Econometrics, 31 , 307-327.

Casillas, J. C. \& Acedo, F. J. (2013). Speed in the internationalization process of the firm. International Journal of Management Reviews, 15(1), 15-29.

Dhungel, K. R. (2014). Estimation of Short and Long Run Equilibrium Coefficients in Error Correction Model: An Empirical Evidence from Nepal. International Journal of Econometrics and Financial Management, 2(6), 214-219.

Engle, R.F. and Granger, C.W.J. (1987). Cointegration and Error Correction: Representation, Estimation and Testing, Econometrica, 55(2), 251-276.

Ganyaupfu, E.M. (2013). The Relative Impacts of Real Exchange Rate Misalignment and Real Exchange Rate Volatility on Export Growth in South Africa. Journal of Economics and Sustainable Development, 4(12), 7077.

Ganyaupfu, E. M. (2014). Fiscal Sustainability in South Africa: Recent Evidence. Journal of Social Economics, $1(4), 159-167$

Ganyaupfu, E.M. \& Robinson, Z.C. (2019). Fiscal Sustainability and Interdependence of Primary Balance and Public Debt in South Africa. Acta Universitatis Danubius Economica, 15(3), 318-334.

Gudaro, A. M., Chhapra, I. U. \& Sheikh, S. A. (2010). Impact of foreign direct investment on economic growth: A case study of Pakistan. J. Manage. Social Sci., 6, 22-30.

Hussain, M. E. \& Haque, M. (2016). Foreign Direct Investment, Trade, and Economic Growth: An Empirical Analysis of Bangladesh. Economies, 4(7), 1-14.

Johansen, S. (1988). Statistical Analysis of Cointegration Vectors, Journal of Economic Dynamics and Control, 12(2-3), 231-254.

Jones, C. I. (2015). The Facts of Economic Growth. Stanford GSB and NBER.

Kalumbu, S.A. \& Sheefeni, J.P.S. (2014). Terms of Trade and Economic Growth in Namibia. International Review 
of Research in Emerging Markets and the Global Economy, 1(3), 90-101.

Koma, S. B. (2013). The trajectory of economic development policies in South Africa: The case for public policy analysis. Administration Publica, 21(1), 142-160.

Mahembe, E. \& Odhiambo, N. M. (2013). The dynamics of foreign direct investment in SADC countries: experiences from five middle-income economies. Problems and Perspectives in Management, 11(4), 35-45.

Mahembe, E. \& Odhiambo, N. M. (2014). A critical review of FDI inflows and economic growth in low-income SADC countries: prospects and challenges. Problems and Perspectives in Management, 12(1), 7-16.

Makwembere, S. (2014). The impact of sector foreign direct investment on economic growth in developing countries. Dissertation. Gordon Institute of Business Science, University of Pretoria, South Africa.

Mazenda, A. (2012). The effect of foreign direct investment on economic growth: Evidence from South Africa. Department of Economics, University of Fort Hare.

Pietersen, P. H. (2015). South African IPAs Attracting FDI: Investment Promotion Strategies. The Journal of Applied Business Research, 31(3), 1057-1072.

Sankran, C. (2015). An analysis of determinates of FDI inflows: The case of the Dominican Republic. Journal of Applied Economics, 14(1), 47-68.

Sherif A. \& Dalia E. I. M. (2014). Determinants of FDI Flows to Developing Countries: An Empirical Study on the MENA Region. Journal of Finance and Economics, 4(1), 30-38.

UNCTAD. (2015). World investment report 2015. By United Nations Conference on Trade and Development, New York: United Nations.

Zafar, A. (2013). The Determinants of Inward FDI in BRICS Countries: Evidence from a Time Series Data Analysis. Journal of Economics and Sustainable Development, 4(5), 105-114. 